\title{
WUJUD TUTURAN MENGKRITIK ROCKY GERUNG TERHADAP PEMERINTAHAN PRESIDEN JOKO WIDODO
}

(Rocky Gerung's Criticizing Forms toward Jokowi Regime)

\author{
Christina Natalina Saragi \\ Universitas HKBP Nommensen \\ Jl. Sutomo. Medan, Indonesia \\ Saragichristina1987@gmail.com
}

(Naskah diterima Tanggal 6 September 2019-Direvisi Tanggal 20 September 2019-Disetujui Tanggal 10 Oktober 2019)

\begin{abstract}
Abstract: The speech of criticism is considered important but the speech of criticism that we say, must be determined its direction. The purpose of this study is to find out why RG, as the subject of this research, uses a strategy of criticizing (directly or indirectly) when discussing discussions about President Joko Widodo's government policies. The research method used is descriptive qualitative. The data of this study are the speech of $R G$ whose data source was obtained from the ILC Talk Show on President Joko Widodo's government policy. The results obtained from this research are the criticism of speech acts strategy used by $R G$ is to criticize directly which includes a negative assessment of $20.16 \%$, denunciation of $16.26 \%$, expression of disagreement $29 \%$, and statement of problem $23.37 \%$ and not directly in the form of advice on change. Based on the data obtained that direct criticism on the expression of contradiction to be the most dominant used by Rocky Cerung caused by several factors including the critical attitude character factors owned by $R G$, educational background factors, and thirdly based on the background of many experiences in possessed by $R G$ made him more courageous in giving criticism especially to the policies of the Joko Widodo government.
\end{abstract}

Keywords: Critisism Speech Act, Direct and Indirect Criticism Speech Act, Talk Show.

\section{PENDAHULUAN}

Bahasa tidak lain adalah subjek dari manusia untuk berinteraksi dalam mengungkapkan, mengatakan apa yang manusia ketahui (Castillo, 2015). Keraf (2001) menyatakan bahwa salah satu fungsi bahasa adalah sebagai alat untuk mengekspresikan sikap diri, hal ini berhubungan erat dengan istilah mengkritik (Searle, 1979). Sebagaimana dijelaskan tindak tutur ekspresif adalah tindak tutur yang mengekspresikan sikap atau keadaan psikologis penutur(Ilyas, 2012). Maka dapat dikatakan bahwa mengkritik merupakan salah satu ekspresi sikap yang diterjemahkan melalui bahasa.

Tindak tutur mengkritik adalah tindak ilokusi yang ilokusi poinnya adalah untuk memberikan evaluasi negatif terhadap tindakan, pilihan, kata-kata dan produkproduk yang menjadi tanggung jawab penutur. Mengkritik dalam konteks ini berarti memberikan komentar, baik berupa pendapat, saran, masukan maupun sanggahan kepada seseorang. Kritik dilakukan dengan harapan dapat mempengaruhi tindakan petutur pada masa yang akan datang agar menjadi lebih baik dan manfaatnya ada pada petutur sendiri. Kritik juga dilakukan untuk menyampaikan ketidakpuasan atau ketidaksukaan penutur mengenai apa yang dilakukan petutur tetapi tanpa menyiratkan bahwa apa yang dilakukan petutur memiliki konsekuensi yang tidak diinginkan bagi penutur.

Menurut Nguyen (2005: 14) tindak tutur mengkritik dapat terbentuk dari berbagai tindak tutur yang berbeda-beda 
yang masing-masing membawa daya ilokusi yang berbeda pula dan tidak ada satupun yang merupakan tindak utama (inti). Sebagai contoh, mengkritik dapat merupakan kompilasi dari ekspresi ketidaksetujuan, evaluasi negatif, statemen tentang tindakan salah, dan saran untuk perbaikan.Maka dapat disimpulkan bahwa tindak tutur mengkritik merupakan tindakan ilokusi yang titik ilokusinya adalah untuk memberikan evaluasi negatif atas tindakan, pilihan katakata, dan produk yang menjadi tanggung jawab petutur. Tindakan ini dilakukan dengan harapan mempengaruhi tindakan petutur di masa depan untuk perbaikan mitra tutur, dilihat oleh penutur sebagai alat berkomunikasi. Ketidakpuasan penutur dengan atau tidak menyukai mengenai apa yang telah dilakukan mitra tutur, akan membawa konsekuensi yang tidak diinginkan untuk penutur(T. T. M. Nguyen, 2008).

Berdasarkan pengertian kritik yang dikemukakan para ahli di atas, ada dua hal penting yang dapat dicatat.Pertama, kritik selalu berkenaan dengan evaluasi negatif atau perasaan negatif atau sikap negatif terhadap perbuatan dan perilaku petutur. Kedua, kritik dilakukan dengan harapan perbuatan petutur menjadi lebih baik pada waktu yang akan datang.

Dewasa ini tindak tutur mengkritik merupakan tindak tutur yang sangat fenomenal yang terjadi di tengah- tengah kehidupan bermasyarakat (Hosseinizadeh, 2019). Tindak tutur mengkritik seolah- olah menjadi hal yang sangat menentukan prestisious seseorang, karena isi kritik yang dituturkan atau disampaikan oleh seseorang pastilah mencerminkan siapa dirinya, apakah isi kritkan yang dituturkan akan membawa kearah yang positif atau bahkan negative yang sampai berujung mengundang kontroversi di tengah-tengah kehidupan bermasyarakat.

Media baik cetak atau online juga seakan tidak ada hentinya memberitakan informasi tentang tuturan mengkritik di semua kalangan masyarakat, baik dari yang muda sampai yang tua, yang miskin sampai yang kaya, masyarakat dengan pemerintah, sesama pemerintah dan disegala lapisan masyarakat (Nurudin, 2017). Terkait dengan mengkritik Nguyen (2005) mengatakan bahwa tindak tutur mengkritik dapat terbentuk dari berbagai tindak tutur yangberbeda-beda yang masing-masing membawa daya ilokusi yang berbeda pula dan tidak ada satupun yang merupakan tindak utama (inti). Sebagai contoh, mengkritik dapat merupakan kompilasi dari ekspresi ketidaksetujuan, evaluasi negatif, statemen tentang tindakan salah, dan saran untuk perbaikan. Tindak tutur mengkritik merupakan tindakan ilokusi yang titik ilokusinya adalah untuk memberikan evaluasi negatif atas tindakan, pilihan katakata, dan produk yang menjadi tanggung jawab petutur. Tindakan dari tindak tutur ini dilakukan dengan harapan mempengaruhi tindakan petutur di masa depan untuk perbaikan mitra tutur, dilihat oleh penutur sebagai alat berkomunikasi. Ketidakpuasan penutur dengan atau tidak menyukai mengenai apa yang telah dilakukan mitra tutur, akan membawa konsekuensi yang tidak diinginkan untuk penutur (T. T. M. Nguyen, 2008: 47--48). Tindak tutur mengkritik dibagi menjadi dua, yaitu tindak tutur mengkritik langsung dan tidak langsung.

1) Mengkritik langsung adalah kritik yang secara eksplisit menunjukkan masalah dengan pilihan, tindakan dan kinerja dari $\mathrm{H}$.

a. Penilaian Negatif: Pada umumnya diekspresikan melalui evaluasi baik negative maupun positif

b. Pencelaan: Menggambarkan sikap penutur terhadap pilihan $\mathrm{H}$ (mitra tutur)

c. Ekspresi Pertentangan: Umumnya diekspresikan dengan kata negasi 'tidak', performatif 'saya tidak setuju'atau tanpa performatif tersebut atau dengan melalui argument terhadap $\mathrm{H}$ (mitra tutur) 
d. Peryataan Masalah: Kesalahan atau masalah yang ditemukan menyatakan pilihan $\mathrm{H}$ (mitra tutur)

e. Pernyataan Kesulitan

f. Konsekuensi: Peringatan tentang konsekuensi negative atau efek negative pilihan $\mathrm{H}$, untuk $\mathrm{H}$ (mitra tutur ) dirinya sendiri atau public.

2) Mengkritik tidak langsung adalah kritik yang menyiratkan masalah dengan pilihan, tindakan,

kinerja atau produk dari $\mathrm{H}$ (mitra tutur)., dengan memperbaiki $\mathrm{H}$, menunjukkan aturan standar, memberikan nasihat, menunjukkan atau bahkan meminta dan menuntut perubahan kerja atau pilihan $\mathrm{H}$, dan dengan cara jenis yang berbeda dari petunjuk untuk meningkatkan kesadaran $\mathrm{H}$ dari ketidaktepatan pilihan $\mathrm{H}$ (mitra tutur).

a. Koreksi: Termasuk semua ujaran yang memiliki tujuan memperbaiki kesalahan dengan menegaskan alternative khusus untuk pilihan $\mathrm{H}$ (mitra tutur)

b. Menunjukkan Standar: Termasuk semua ujaran yang memiliki tujuan memperbaiki kesalahan dengan menegaskan alternative khusus untuk pilihan $\mathrm{H}$ (mitra tutur).

c. Permintaan Perubahan: Tuntutan PerubahanBiasanya diekspresikan melalui struktur seperti 'anda harus', ítu adalah wajib bahwa' atau 'anda diminta' atau 'anda diminta' atau 'anda perlu'.

d. Permintaan: PerubahanBiasanya diekspresikan melalui struktur seperti 'ya..."' 'bisa....?', atau imperative (dengan atau tanpa penanda kesantunan), atau ingin pernyataan, atau tanpa adanya struktur tersebut melainkan menggunakan permintaan perubahan.

e. Nasehat Perubahan: Biasanya diungkapkan melalui ujaran 'saya menyarankan anda...', atau struktur dengan 'seharusnya' dengan atau tanpa ujaran tersebut.

f. Saran: Perubahanbiasanya dinyatakan melalui performatif 'saya menyarankan agar...' 'seperti 'itu akan lebih baik jika...' atau tanpa ujaran tersebut.

g. Ekspresi: Ketidak PastianUngkapan untuk mengekspresikan ketidakastian $\mathrm{S}$ dan untuk meningkatkan kesadaran $\mathrm{H}$ dari ketidaktepatan pilihan $\mathrm{H}$ (mitra tutur).

h. Mengajukan/Mengandaikan: Pertanyaan retorik untuk meningkatkan kesadaran $\mathrm{H}$ dari dalam kesesuaian pilihan $\mathrm{H}$ (mitra tutur).

i. Petunjuk Lain: Termasuk jenis lain dari petunjuk yang bukan milik keduaduanya. Mungkin termasuk sarkasme.

Tujuan dari mengkritik adalah untuk memperbaiki pendapat/perilaku seseorang dan bukan didasarkan atas kebencian terhadap orangnya. Selain itu perlu juga di berikan berbagai macam alasan dan buktibukti yang kuat sehingga orang itu menyadari kesalahannya. Dalam menyampaikan kritik tentunya juga seseorang harus berbicara dengan efektif, sehingga pembicaraannya bisa ditangkap dengan mudah oleh orang yang kita kritik. Kadang kala yang lebih sulit adalah untuk memilih kata-kata yang tidak menyinggung perasaan. Pada intinya carilah kata-kata yang sopan dan bijaksana, tetapi tetap tidak mengurangi esensi kritiknya.

Kegiatan mengkritik biasanya ditampung dalam sebuah wadah yang tidak asing lagi kita dengar yaitu "Talk Show", sepertinya yang sangat terkenal pada saat ini adalah Indonesia Lawyers' Club. Salah satu talk show yang menyajikan pendapat bahkan kritikan terhadap apa saja yang dianggap fenomenal dimasyarakat. Acara ini biasanya diisi oleh bintang tamu yang berasal dari latar belakang pendidikan, pekerjaan, serta umur dan lain- lain yang berbeda. Para tamu undangan bebas mengexspresikan dirinya dalam wujud tuturan baik mengkritik, memberi saran. Di acara Indonesia Lawyers' $C l u b$, tidak jarang kita dapat melihat para tamu yang diundang sebagai pembicara atau bintang tamu beradu argument, mengkrtik 
samapi berujung dengan tidak dapatnya mengendalikan diri sehingga muncul lah perdebatan yang terkadang sulit untuk di redakan.

Seperti baru-baru ini yang terjadi di masyarakat yang sangat mengejutkan dengan adanya kritik yang sangat fenomenal bahkan dianggap meresahkan masyarakat luas bahkan berujung kepada pelaporan ke pihak berwajib, yang mana kritikan tersebut datang dari Rocky Gerung. Rocky Gerung (RG) adalah seorang staff pengajar di Departemen Fakultas Ilmu Pengetahuan Budaya Universitas Indonesia yang juga merupakan seorang peneliti Perhimpunan Pendidikan Demokrasi. RG lahir di Manado pada 20 januari 1959. Ia menempuh studinya di Universitas Indonesia pada tahun 1986 dan memperoleh gelar sebagai sarjana sastra Universitas Indonesia. RG diketahui sering menyampaikan kritik keras kepada kebijakan pemerintahan Presiden Joko Widodo. Sosok RG sangat menarik untuk dijadikan subjek penelitan karena ketika memberikan tuturan mengktitik, isi kritikannya dianggap frontal terlebih ketika kritikan tersebut dialamatkan terhadap pemerintahan Presiden Joko Widodo.

Penelitian terkait dengan tindak tutur mengkritik sudah pernah dilakukan oleh beberapa peneliti sebelumnya, antara lain adalah penelitian Asih (2014) yang membahas tentang tindak tutur mengkritik dalam acara Sentilan-Sentilun di Metro TV. Hasil penelitian Asih tersebut menunjukkan bahwa tindak tutur mengkritik yang banyak ditemukan adalah tindak tutur mengkritik langsung dengan melakukan pencelaan, sedangkan penelitian ini menemukan tindak tutur mengkritik langsung dengan memberikan ekspresi pertentangan sebagai tindak tutur yang paling dominan. Perbedaan hasil penelitian ini dipengaruhi oleh beberapa faktor yang antara lain adalah pemilihan subjek yang diteliti dan topik. Pemilihan subjek yang diteliti sangat berpengarung sebab RG sebagai subjek yang diteliti merupakan orang yang sangat frontal dan berani dalam memberikan kritikan terhadap topic yang dibicarakan yaitu tentang kebijakan pemerintahan Presiden Joko Widodo. Topik yang dibahas tersebut langsung mengacu kepada orang yang paling penting atau orang nomor satu di Republik Indonesia.

Penelitian terdahulu yang berikutnya adalah penelitian (Farnia \& Sattar, 2015) yang berjudul A Sociopragmatic Analysis of the Speech Act of Criticism by Persian Native Speakers. Perbedaan penelitian Farnia \& Sattar (2015) dengan penelitian ini terletak pada metodologi pengumpulan data. Data yang dipakai Farnia \& Sattar dikumpulkan melalui kuessioner sedangkan penelitian ini data diperoleh melalui tuturan yang langsung diutarakan oleh subjek yang diterili yaitu RG. Kelebihan dari pengambilan data melalui tuturan dari dalam sebuah dialog memberikan pasokan data yang natural.

Peneliti terdahulu yang ketiga adalah (Nofrita, 2016). Dalam penelitiannya yang berjudul Tindak Tutur Ekspresif Mengkritik Dan Memuji Dalam Novel Padang Bulan Dan Cinta Di Dalam Gelas Karya Andrea Hirata ditemukan perbedaan pada sumber pemerolehan data. Nofrita (2016) menggunakan novel sebagai sumber pemerolehan data. Pada penelitian ini sumber pemerolehan data didapat dari dialog langsung oleh subjek yang diteliti melalui program TV ILC yang tayang di TV One. Secara otomatis muatan pembahasan pun jauh berbeda.

Peneliti terdahulu yang keempat adalah (Nugroho, 2017). Dalam penelitiannya yang berjudul Kritikan dan Tindak Tutur Mengkritik dalam Tiga Lagu Iwan Fals Versi Konser." Ditemukan perbedaan pada sumber data dan teori analisi sata yang digunakan. Sumber data yang digunakan dalam penelitian terdahulu adalah tiga lagu dari Iwan Fals sementara pada penelitan ini adalah tuturan langsung dari sosok RG yang pad penelitian ini merupakan subjek yang diteliti, adapun dialog tersebut ditayangkan pada acara ILC di TV One, kemudian teori analisi data yang 
digunakan pada penelitian terdahulu menggunakan teori Wijana untuk mengklasifikasi tuturan mengkritik sedangkan pada penelitian ini peneliti menggunakan teori Nguyen (2008) untuk mengklasifikasi tuturan mengkritik.

Adapun tujuan penelitian dari mereka adalah mengklasifikasikan atau menggolongkan kedalam jenis apakah tindak tutur mengkritik disampaikan (Apakah disampaikan secara langsung atau tidak langsung). Adapun perbedaan penelitian yang akan dilakukan adalah bukan hanya sekedar mengklasifikasikan (langsung atau tidak langsung) Tindak tutur mengkritik saja akan tetapi menemukan dan mendeskripsikan alasan mengapa tindak tutur mengkritik dituturkan (secara langsung atau tidak langsung) mendominasi dalam tuturan RG . Tujuan dari penelitian ini adalah untuk mendeskripsikan alasan mengapa RG menggunakan tindak tutur yang (langsung dan tidak langsung) terhadap pemerintahan Bapak Presiden Joko Widodo. Adapun yang menjadi manfaat teoritis adalah memperkaya penelitian dibidang pragmatik terkait dengan tindak tutur mengkritik dan secara praktis penelitian ini dapat dijadikan panduan dalam hal cara mengkritik oleh masyarakat ketika mengkritisi permasalahan yang terjadi di Pemerintahan. Adapun teori yang digunakan untuk menganalisis data adalah teori Nguyen (2008:47-48)

\section{METODE PENENLITIAN}

Jenis penelitian ini masuk pada ranah studi kasus (Creswell, 2014) karena peneliti menyelidiki secara cermat isi tuturan dari RG dalam memberikan tuturan mengkritik terhadap kebijakan pemerintahan Presiden Joko Widodo. Data penelitian berupa tuturan yang menandung tindak tutur mengkritik yang dituturkan oleh RG dalam acara Indonesia Lawyers' Club. Dalam penelitian ini, tempat dilakukan pengambilan data adalah dalam Video talk show yang berjudul "Indonesia Lawyers' $C l u b$ yang temanya adalah "Kritik Keras RG kepada Pemerintahan Joko Widodo". Video ini diputar melalui youtobe. Partisipannya adalah RG. Tindak tutur RG dalam mengkritik menjadi objek penelitian ini. Data dari penelitian ini merupakan tuturan yang mengandung makna tindak tutur mengkritik dari tuturan $\mathrm{RG}$ dalam video talk show tersebut. Adapun teknik pengumpulan data nya adalah:

1. Observasi dan studi pendahuluan (mendengarkan terlebih dahulu video talk show yang berjudul "Indonesia Lawyers' Club "yang temanya adalah "Kritik Keras RG kepada Pemerintahan Joko Widodo"

2. Lalu ditranskrip otografis

3. Simak dan catat transkrip otografis

4. Setelah ditemukan, diklasifikasikan kembali ke tipe tindak tutur mengkritik seperti menurut Nguyen yaitu langsung atau Tidak langsung berdasarkan karakteristik kedua tipe tindak tutur mengkritik tersebut.

Adapun analisis data yang digunakan dalam penelitian ini adalah teori dari Nguyen (2008) untuk mengklasifikasi tuturan mengkritik yang dituturkan oleh RG terhadap kebijakan pemerintahan Presiden Joko Widodo dikategorikan sebgai tindak tutur mengkritik langsung atau Tidak langsung.

\section{PEMBAHASAN}

Berdasarkan analisis data yang diambil dari beberapa sumber talk show yang berbeda, ditemukan strategi tindak tutur mengkritik secara langsung dan juga tidak langsung. Berikut uraian tindak tutur mengkritik tersebut.

\section{Tindak Tutur Mengkritik Dengan Strategi Langsung}

Tindak tutur mengkritik langsung merupakan tuturan mengkritik yang disampaikan secara eksplisit, terus terang, 
tanpa basa basi terhadap pilihan, tindakan, kata- kata atau lainnya yang dilakukan oleh mitra tutur. Data mengenai tindak tutur langsung yang ditemukan pada penelitian ini meliputi pernyataan masalah, pencelaan, penilaian negative, Ekspresi pertentangan dan konsekuensi.

\section{Ekspresi Pertentangan}

Tuturan mengkritik RG lebih dominan pada tindak tutur langsung yang diwujudkan dengan ekspresi pertentangan sebanyak 38 tuturan. Ekspresi pertentangan menjadi tindak tutur yang paling dominan ditemukan pada penelitian ini dikarenakan sosok $R G$ yang memiliki sikap yang frontal dan berani dalam meberikan kritikan terhadap kebijakan pemerintahan Presiden Joko Widodo.

Ekspresi pertentangan biasanya diwujudkan dengan kata negasi tidak atau performatif 'saya tidak setuju atau saya setuju', dengan atau tanpa modal. Data yang menunjukka tindak tutur mengkritik langsung 'ekspresi pertentangan' dapat diihat pada data berikut ini.

\section{Konteks: \\ RG (Politisi yang kontra terhadap kebijakan Presiden Joko Widodo) mengkritik isi ucapan Joko Widodo (Presiden RI), yang mana beliau mengatakan Bahwa "Jangan membaca Joko Widodo Undercover karena buku itu tidak ilmiah" RG: "Sore tadi saya baca, Pak Joko Widodo bilang, 'Jangan membaca Joko Widodo Undercover karena buku itu tidak ilmiah'. Saya anggap itu hoax," "Karena yang ngomong itu adalah presiden, memberi penilaian pada buku tidak ilmiah. Dari sudut pandang definisi lho, yang berhak menentukan suatu buku ilmiah atau tidak adalah kampus akademisi.}

Kritikan yang disampaikan oleh RG kepada isi ucapan Presiden Joko Widodo tersebut dapat diklasifikasikan terhadap tindak tutur mengkritik langsung. Ini dapat dibuktikan melalui tuturan yang dituturkan oleh RG.
Tuturan yang dituturkan oleh RG itu disampaikan sangan jelas dan dapat dimengerti. RG berusaha untuk mengutarakan melalui tuturannya yang bermaksud untuk mengkrtik isi ucapan dari Presiden Joko Widodo.

Jenis mengkritik langsung pada tuturan yang dituturkan oleh RG yaitu tuturan (1) Saya anggap itu hoax, Karena yang ngomong itu adalah presiden, memberi penilaian pada buku tidak ilmiah dan tuturan (2)yang berhak menentukan suatu buku ilmiah atau tidak adalah saya atau kampus sebagai akademisi"termasuk dalam kategori 'ekspresi pertentangan karena makna tuturan yang dituturkan oleh RG mengandung makna ketidak setujuan atas isi ucapan dari Presiden Joko Widodo yang mengatakan bahwa "Jangan membaca Joko Widodo Undercover karena buku itu tidak ilmiah'. Tuturan RG tersebut dituturkan dikarenakan dia berusaha untuk menentang melalui tuturan yang berisi kritikan kepada ucapan Presiden Joko Widodo yang beliau anggap tidak pantas dalam menilai ilmiah atau tidaknya sebuah buku, ekspresi pertentangan RG dilanjutkan kembali dengan memberikan kritikan terhadap isi ucapan Presiden Joko Widodo dengan menuturkan tuturan yaitu 'yang berhak menentukan suatu buku ilmiah atau tidak adalah saya atau kampus sebagai akademisi '. Maka dapat disimpulkan bahwa tindak tutur mengkritik langsung dengan ekspresi pertentangan dapat terjadi karena adanya ketidak setujuan terhadap suatu pernyataan.

\section{Pernyataan Masalah}

Pernyataan masalah adalah kemampuan seseorang dalam menggambarkan suatu permasalahan atau yang sedang terjadi yang mana dinyatakan secara jelas baik dalam bentuk tulisan maupun lisan atau berupa tuturan.

Konteks : Joko Widodo, selaku Presiden RI memberikan reaksi terhadap isi pidato Prabowo (Politi yang kontra terhadap 
pemerintahan) tentang pergantian Presiden tahun 2019. RG (Politikus yang kontra terhadap pemerintahan Joko Widodo) mengkritik Presiden Joko Widodo karena beliau bereaksi terhadap isi pidato Prabowo tersebut dan reaksinya (Presiden Joko Widodo) dianggap tidak benar sebab tidak masuk diakal dikarenakan isi pidato tersebut belum terjadi.

RG:

Reaksi presiden terhadap pidato prabowo, tetapi ada yang palsu didalam cara presiden beraksi itu, dia (Presiden Joko Widodo) pasti palsu karena dia beraksi terhadap pidato, jadi presiden tidak berpidato, dia bereaksi terhadap pidato. Reaksi pertama terhadap kaos dengan hastag tadi itu kaos 2019 ganti Presiden, lho hastag itu adalah fiksi, ngapain bereaksi terhadap fiksi, kan belum terjadi 2019 pergantian Presiden, jadi siapa yang ngajari Presiden bereaksi terhadap fiksi, reaksi terhadap fiksi hasilnya fiksi juga

Kritikan yang disampaikan oleh $\mathrm{RG}$ di atas termasuk dalam jenis tindak tutur mengkritik "langsung" . karena secara jelas dapat dilihat bahwa tuturan yang dituturkan tersebut diungkapakan secara tegas, dan tidak berbelit belit. Maksud tuturan yang dituturkan juga tidak memiliki gambaran yang kabur. Daya ilokusi yang hendak disampaikan dalam tuturan tersebut mempunyai tujuan untuk menyampaikan sebuah kritikan. RG menyampaikan kritikan terhadap sikap Presiden Joko Widodo terhadap isi pidato dari Prabowo yang semestinya tidak perlu ditanggapi karena yang dilakukan Joko Widodo tersebuat merupakan pekerjaan yang sia-sia.

Tuturan juga diklasifikasikan kedalam tindak tutur mengkrtik langsung 'pernyataan masalah, karena sangat jelas dapat dimengerti maksud dari tuturan RG adalah memperlihatkan bahwa ada suatu masalah atau kesalahan yang telah dilakukan oleh Presiden Joko Widodo, ini dapat dibuktikan dari tuturannya yang menyatakan yaitu 'tetapi ada yang palsu didalam cara presiden beraksi itu, dia (Presiden Joko Widodo) pasti palsu karena dia beraksi terhadap pidato'. Bukan hanya itu tuturan dari RG yang menyatakan "Reaksi pertama terhadap kaos dengan hastag tadi itu kaos 2019 ganti Presiden, lho hastag itu adalah fiksi,ngapain bereaksi terhadap fiksi, kan belum terjadi 2019 pergantian Presiden, jadi siapa yang ngajari Presiden bereaksi terhadap fiksi,reaksi terhadap fiksi hasilnya fiksi juga", itu juga berupa kritikan pernyataan masalah terhadap reaksi Presiden Joko Widodo terkait pidato Prabowo, dalam kritikannya Rocky menegaskan bahwa yang dilakukan oleh presiden Joko Widodo adalah fiksi sebab belum terjadi.

\section{Pencelaan}

Pencelaan adalah tuturan yang menggambarkan sikap penutur terhadap pilihan yang dilakukan mitra tutur (Nguyen, 2008:47). Data yang menunjukkan tindak tutur mengkritik langsung pencelaan dapat dilihat pada data berikut ini.

Konteks:
RG mengkritik dengan menilai
bagaimana gaya Presiden Joko
Widodo ketika sedang berpidato
didepan pers.
RG:
"Yang ada sekarang Presiden, untuk
menemukan satu kalimat, ia buka
halaman satu- satu sampai dia tidak
bisa menemukan gugup di depan
michrophone, terbaca oleh pers dunia,
maka yang malu bukan hanya Presiden
dan timnya, saya sebagai warga
Negara, malu melihat Presiden, gugup
dan gagap, bodoh di depan pers Dunia.
Lalu orang marah dibilang dungu, jadi
dibilang apa?, kurang baca masih
kasar, kurang mampu memanfaatkan
akal yang diberikan Tuhan
kepadanya."

Tuturan dari RG masuk pada mengkritik langsung tergolong dalam strategi 
kritikan'pencelaan' karena dalam tuturan tersebut RG memberikan kritik dengan pencelaan. Itu dapat dilihat dari tuturan yaitu Yang ada sekarang Presiden, untuk menemukan satu kalimat, ia buka halaman satu- satu sampai dia tidak bisa menemukan gugup di depan michrophone, terbaca oleh pers dunia, maka yang malu bukan hanya Presiden dan timnya, saya sebagai warga Negara, malu melihat Presiden,gugup dan gagap, bodoh di depan pers Dunia. Lalu orang marah dibilang dungu, jadi dibilang apa?, kurang baca masih kasar, kurang mampu memanfaatkan akal yang diberikan Tuhan kepadanya. Dapat ditangkap bahwa maksud dari tuturan adalah benar- benar mencela Presiden Joko Widodo. Dalam tuturannya RG menuturkan bahwa Presiden gugup, dan gagap, bodoh didepan pers dunia. Itu merupakan bentuk pencelaan yang dimaksudkan untuk menurunkan harga diri dari Presiden Joko Widodo.

\section{Penilaian Negatif}

Penilaian adalah tuturan yang pada umumnya dikspresikan melalui penilaian yang bersifat negative maupun yang bersifat positif. Data yang menunjukkan tindak tutur mengkritik langsung penilaian negative. Tindak tutur lamgsung yang diwujudkan dengan memberi penilaian negatif hanya pantas disampaikan oleh orang yang lebih berkompeten memberikan penilaian negative itu sendiri. Ditunjukkan melalui tuturan berikut ini.

Konteks:

RG mengkritik isi ucapan Presiden Joko Widodo tentang terror pemuka agama, dikarenakan tuturan dari Presiden Joko Widodo tersebut justru dapat membuat perpecahan pada kehidupan politik

RG:

"namun justru presiden menambah kecemasan pada kehidupan politik kita melalui statment-nya."Saat itu pak Joko Widodo bilang: Mereka yang intoleran

tidak ada tempat,itu reaksi presiden yang justru menambah kecemasan
kita,".Kritikan yang disampaikan oleh RG diatas termasuk dalam jenis tindak tutur mengkritik 'langsung'. Tindak tutur mengkritik langsung terlihat pada tuturan" namun justru presiden menambah kecemasan pada kehidupan politik kita melalui statment-nya."Saat itu pak Joko Widodo bilang :Mereka yang intoleran tidak ada tempat' dan Itu reaksi presiden yang justru menambah kecemasan kita,"Tuturantuturan dari RG tersebut dikatakan kritik langsung karena isi kritikan yang dituturkan oleh RG tersebut diungkapkan secara tegas, jelas, dan tidak berbelit- belit. Maksud tuturan tersebut jelas tidak kabur. Tujuan tuturan yang disampaikan oleh RG dapat diterima oleh pembaca sebagai kritik langsung.

Tindak tutur mengkritik yang disampaikan oleh RG diatas termasuk dalam jenis stategi tindak tutur mengkritk langsung' penilaian negative karena dalam tuturan tersebut terdapat makna penilaian negative dengan penanda yang maknanya negatif atau buruk yaitu" justru menambah kecemasan. Melalui phrase yang telah dituturkan, penilaian negative atau buruk semakin jelas dimaknai dalam tuturan yang dituturkan oleh $\mathrm{RG}$, karena tuturan dari RG ternyata memberikan makna bahwa adanya gambaran yang buruk berupa kecemasan yang berujung ketidak nyaman dalam kehidupan perpolitikan Indonesia akibat adanya isi statement yang dituturkan oleh Presiden Joko Widodo.

\section{Tindak Tutur Mengkritik Dengan Strategi Tidak Langsung}

Tindak tutur mengkritik tidak langsung adalah tuturan yang menyiratkan permasalahan dengan pilihan, tindakan, kinerja, dari mitra tutur. Pada penelitian tindak tutur mengkritik tidak langsung ini ditemukan 1 macam subtindak tutur mengkritik tidak langsung yaitu nasehat perubahan

\section{Nasehat Perubahan}

Nasehat perubahan yaitu tuturan yang berupa nasehat untuk perubahan pilihan atau 
kinerja mita tutur. Biasanya diungkapkn melalui perfomatif" Saya menyarankan anda antau seharusnya". Data yang menunjukkan tindak tutur mengkritik tidak langsung 'nasehat perubahan' dapat dilihat pada data berikut ini.

\section{Kontek s: \\ RG mengkritik dengan cara memberikan nasehat perubahan terhadap isi pidato dari bapak Presiden Joko Widodo, yang mana beliau melalui statment-nya mengatakan "Saat itu pak Joko Widodo bilang: Mereka yang intoleran, tidak ada tempat. \\ RG: \\ "Seharusnya presiden memberikan statemen yang membuat teduh"}

Pada tuturan data (5) disampaikan oleh RG sebagai narasumber dalam talk show. Tuturan yang dituturkan oleh RG tersebut merupakan tuturan yang tujuannya mengkritik, karena tuturan yang dituturkan tujuannya adalah mengkritik suatu objek kearah yang lebih baik, dalam hal iniyang merupakan objek adalah tuturan dari Presiden Joko Widodo.

Tindak tutur mengkritik yang disampaikan oleh $\mathrm{RG}$ tersebut dapat diklasifikasikan kedalam strategi mengkritik tidak langsung termasuk dalam tindak tutur tidak langsung karena tuturan yang disampaikan oleh RG diungkapakan secara jelas dan tidak ambigu. Ini dikarenakan tuturan tersebut mempunyai tujuan untuk menasehati.

Kritikan yang disampaikan oleh RG termasuk dalam tindak tutur mengkritik tidak langsung 'nasehat perubahan'. Strategi 'nasehat perubahan tampak pada tuturan' Seharusnya Presiden memberikan statemen yang membuat teduh. Kata seharusnya menunjukkan sebuah bentuk pemberian anjuran yang baik dari penutur yang dalam hal ini penuturnya adalah RG.

Berdasarkan tabel di bawah ini, dapat ditunjukkan bahwa RG lebih banyak menuturkan tindak tutur mengkritik lamgsung pada bagian ekspresi pertentangan yaitu sebanyak 38 tuturan atau sekitar 29,00 $\%$. Dominasi terhadap tuturan mengkritik langsung pada sub ekspresi pertentangan yang dituturkan oleh RG terjadi karena dilatar belakangi oleh beberapa factor. Seperti pada tabel berikut ini:

Tabel 1. Tindak Tutur Mengkritik RG Terhadap Kebijakan Presiden Joko Widodo

\begin{tabular}{llll}
\hline No & Jenis & Jumlah & Persen- \\
& Tindak & Tuturan & $\begin{array}{l}\text { tase dari } \\
\text { Tutur }\end{array}$ \\
& Mengkriti & & Jumlah \\
& k & & Tuturan \\
\hline
\end{tabular}

A. Mengkriti $\mathrm{k}$ Langsung

1 Pernyataan $28 \quad 21,37 \%$

2 Masalah $\quad 38 \quad 29,00 \%$

3 Pencelaan $20 \quad 15,26 \%$

4 Penilaian $27 \quad 20,61 \%$

Negatif

$$
\begin{aligned}
& \text { B. Mengkrit } \\
& \text { ik Tidak } \\
& \text { Langsun } \\
& \text { g }
\end{aligned}
$$

1 Nasehat 18 $13,74 \%$

\begin{tabular}{llll} 
& Perubahan & & \\
\hline To & Jumlah & 131 & $\mathbf{1 0 0 \%}$ \\
tal & Total & & \\
& Keseluruh & & \\
& an & & \\
& Tuturan & & \\
\hline
\end{tabular}

Faktor pertama adalah karakteristik kritis yang dimiliki oleh RG dalam tuturannya. Sesuai pendapat yang dikemukakan oleh (Marlina \& Harahap, 2018). Berpikir kritis dicirikan dengan: bertanya secara jelas dan beralasan, berusaha memahami dengan baik, 
menggunakan sumber yang terpercaya, mempertimbangkan situasi secara keseluruhan, 8980 tetap mengacu dan relevan ke masalah pokok, mencari berbagai alternatif, bersikap terbuka, berani mengambil posisi, bertindak cepat, bersikap atau berpandangan bahwa sesuatu adalah bagian dari keseluruhan yang kompleks, memanfaatkan cara berpikir kritis orang lain yang kritis, dan bersikap sensitif terhadap perasaan orang lain. Berikut tuturan mengkritik langsung yang mengandung makna ekspresi pertentangan dari RG.

Konteks:

Rocky mengyindir bahwa mengisi diskusi Politik Sehat Politik Berakal Muda. Berkarya untuk Indonesia, di Denpasar, Bali, Sabtu (9/3).

RG:

"Ekonomi kita tumbuh 5,1 persen baik atau buruk? Ada yang bilang baik bila ekonomi sebelumnya 3 persen. Selama bapak SBY 10 tahun memimpin angka pertumbuhan ekonominya $6,1-6,2-6,3$ masa iya lebih bagus daripada 5,3? Ini disebut sebagai penipuan-penipuan sistematis"

Pernyataan ini sangat sesuai dengan temuan yang memperlihatkan bahwa tuturan mengkritik RG didominasi oleh mengkritik langsung pada ekspresi pertentangan karena secara logis orang yang memiliki karakter kritis akan lebih jeli, detail dan objektif ketika memberikan kritikan terhadap sesuatu. Kemampuan mereka yang jeli, detail dan objektif menunjukkan bahwa ketika mereka menuturkan tindak tutur mengkrtik langsung maka tuturannya lebih banyak fokus terhadap ekspresi pertentangan. Ini dibuktikan melalui tuturan RG. Ekspresi pertentang yang dituturkan oleh Rocky terlihat dari tuturan nya yang mengatkan bahwa "Selama bapak SBY 10 tahun memimpin angka pertumbuhan ekonominya 6,1-6,2-6,3 masa iya lebih bagus daripada 5,3? Ini disebut sebagai penipuan-penipuan sistematis. Tuturan ini dipengaruhi oleh karakter kritis yang dimiliki oleh RG.

Faktor kedua adalah latar belakang pendidikan, menurut Ridwanuddin (2015) belajar filsafat mengarahkan seseoranguntuk berpikir kritis dalam menghadapi suatu persoalan. Hasil dari berpikir kritis tersebut dapat membentuk seseorang ketika memberikan argumen dalam bentuk lisan maupun tulisan secara sistematis dan kritis, mengkomunikasikan ide secara efektif, dan mampu berpikir secara logis dalam menangani masalah-masalah kehidupan yang selalu tak terduga.

\section{Konteks:}

Rocky lalu memaparkan soal promosi kelebihan pasokan listrik yang digaungkan pemerintah. Rocky menuding promosi itu palsu dan menduga ada pemilik industri besar yang hengkang dari Indonesia. RG:

"Sekarang ada promosi baru bahwa kelebihan pasokan listrik, kita kaget, kapan dibangun power land tiba-tiba ada kelebihan listrik dengan akal sehat kita mengerti, pasti Jawa kelebihan pasokan karena industri besar pemakai listrik hengkang dari Jawa maka ada kapasitas yang tidak terpakai. Itu sama dengan mengatakan ada rumah kos yang klaim bulan ini kami kelebihan listrik, loh kenapa kelebihan listik ya karena anak kosnya sudah pulang nggak dipakai lagi, sama,”.

Latar belakang pendidikan sangat berpengaruh terhadap cara berkomunikasi seseorang yang mana dalah hal ini komonikasi yang dimaksud adalah menuturkan tindak tutur mengkritik secara langsung dengan memberikan ekspresi pertentangan terhadap suatu objek. Latar belakang pendidikan yang dimiliki oleh RG yaitu politik dan filsafat menjadikan $R G$ mengkitik menghasilkan bahasa yang kritis, sistematis, rasional dan efektif terkait pada kebijakan pemerintahan Presiden Joko Widodo, itu terlihat dari tuturan diatas yang mana kritis ditunjukkan dari tuturannya yang 
menyatakan "Sekarang ada promosi baru bahwa kelebihan pasokan listrik, kita kaget ,kapan dibangun power land tiba-tiba ada kelebihan listrik dengan akal sehat kita mengerti". Rasional ditunjukkan dari tuturannya yaitu "Jawa kelebihan pasokan karena industri besar pemakai listrik hengkang dari Jawa maka ada kapasitas yang tidak terpakai. Itu sama dengan mengatakan ada rumah kos yang klaim bulan ini kami kelebihan listrik, loh kenapa kelebihan listik ya karena anak kosnya sudah pulang nggak dipakai lagi, sama,. Tuturan tersebut terjadi karena dilatar belakangi oleh pendidikan RG.

Faktor ketiga adalah latar belakang banyaknya jam terbang atau pengalaman sehingga menjadikan seseorang lebih memiliki keberanian dalam menganalisa suatu objek. Menurut Susanti (2014) kemampuan berpikir merupakan ketrampilan kognitif yang memungkinkan seseorang untuk memahami informasi, mengekspresikan konsep yang kompleks, mengkritik, memecahkan maslah, serta membuat keputusan. Seperti dalam konteks ini RG memiliki keberanian dalam menganalisa kebijakan pemerintah yang diwujudkan dalam tuturannya yang maknanya ekspresi pertentangan. Berikut datanya.

Konteks:

Rocky menyebut banyak penipuan yang dilakukan oleh pemerintah. Dia pun mengaku tak pernah percaya dengan data-data statistik yang dikeluarkan pemerintah.

RG:

"Jadi ada banyak penipuan terjadi tanpa penjelasan apa dasarnya dan saya mengkritik itu supaya tidak dibungkam dengan cara bodoh oleh statistik oleh infografis macammacam. Kalau ada yang mengatakan misalnya tidak ada kesenjangan di antara kita, sering saya terangkan, yang bilang dilaporkan pemerintah kepada publik yang namanya gini rasio, indeks gini itu tentang spending future tentang pengeluaran orang, bukan pemasukannya,".

Berdasarkan tuturan diatas menunjukkan bahwa pengalaman yang dimiliki oleh RG dalam menganalisa membawa pengaruh terhadap tuturan mengkritik yang dituturkan dalam menanggapi kebijakan pemmerintahan Joko Widodo. Adapun itu diwujudkan pada tuturan yang menyatakan "Jadi ada banyak penipuan terjadi tanpa penjelasan apa dasarnya dan saya mengkritik itu supaya tidak dibungkam dengan cara bodoh oleh statistik oleh infografis macam-macam. Rocky dapat menuturkan itu dengan jelas tanpa ragu-ragu sebab dia sudah memiliki banyak pengalaman terkait menganalisa kebijakan Presiden Joko Widodo.

\section{PENUTUP}

Berdasarkan temuan dan pembahasan ditemukanlah kesimpulan mengapa mengkritik langsung dengan ekspresi pertentangan merupakan tuturan yang paling banyak digunakan oleh RG ketika mengkritik kebijakan pemerintah dilatarbelakangi oleh beberapa faktor yang antara lain adalah faktor karakteristik dari diri RG yang kritis diwujudkan dalam tuturannya yang kritis dalam mengktik kebijakan pemerintahan Presiden Joko Widodo. Kemudian faktor yang kedua adalah latar belakang pendidikan. Latar belakang pendidikan yang dimiliki oleh RG yang berasal dari poliyik dan Filsafat menjadikan RG menjadi seorang yang memiliki rasional yang tinggi dalam menuturkan tindak tutur mengkritik, kemuadian sistematis serta efektifitas yang juga ditunjukkan dari tuturan ketika memberikan kritikan langsung terhadap kebijakan pemerintahan Joko Widodo. Yang terakhir adalah faktor latar belakang banyaknya jam terbang atau pengalaman sehingga menjadikan seseorang lebih 
memiliki keberanian dalam menganalisa suatu objek.

\section{DAFTAR PUSTAKA}

Asih, I. N. (2014). Tindak Tutur Mengkritik Dan Strategi Kesantunan Dalam Acara Sentilan Sentilun Di Metro TV. Sebelas Maret.

Castillo, J. M. (2015). The Speech Act as an Act of Knowing. International Journal of Language and Linguistics.

Creswell, J. W. (2014). Research Design: Qualitative, Quantitative and Mixed Methods Approaches (4th ed.). Thousand Oaks,CA: Sage.

Farnia, M., \& Sattar, H. Q. A. (2015). A Sociopragmatic Analysis of the Speech Act of Criticism by Persian Native Speakers. International Journal of Humanities and Cultural Studies, 2(3), 305-323.

Hosseinizadeh, S. H. (2019). Critism Strategies and Their Underlying Cultural Norms in Online Interaction: A study of native Speaker of Persian and English. Journal of International and Intercultural Communication, 12(3).

Ilyas, S. (2012). Facebook Status Updates: A speech Act Analysis. Journal of Academic Research International, 3(2).

Keraf, G. (2001). Komposisi: Sebuah Pengantar Kemahiran Bahasa. Ende: Nusa Indah.

Marlina, E., \& Harahap, E. (2018). Mengembangkan Kemampuan Berpikir Kritis dan Resiliensi Melalui Pembelajaran Program Linier Berbantuan QM for Windows. Jurnal Matematika, 17(2).

Nguyen, M. (2005). Criticizing and responding to criticism in a foreign language: A study of Vietnamese learners of English. The University of Auckland.

Nguyen, T. T. M. (2008). Modifying L2 criticisms: How learners do it? Journal of Intercultural Pragmatic.

Nofrita, M. (2016). Tindak Tutur Ekspresif Mengkritik Dan Memuji Dalam Novel Padang Bulan Dan Cinta Di Dalam Gelas Karya Andrea Hirata. Jurnal Pendidikan Rokania, 1(1), 51--60.

Nugroho, B. (2017). Kritikan dan Tindak Tutur Mengkritik dalam Tiga Lagu Iwan Fals Versi Konser. Universitas Sanata Dharma Yogyakarta.

Nurudin. (2017). Pengantar Komunikasi Massa. Jakarta: PT Raja Girafindo Persada.

Ridwanuddin, D. (2015). Filsafat Pendidikan sebagai Basis Penguat Profesionalisme Guru. Jurnal Qathruna, 2(2).

Searle, J. (1979). Expression and Meaning: Studies in the Theory of Speech Acts. New York: Cambridge University Press.

Susanti, E. (2014). Higher Order Thinking Skills. Bandung: Universitas Pendidikan Indonesia. 